\title{
PREDICTION OF COLONIZATION BY MACROPHYTES IN THE YACIRETÁ RESERVOIR OF THE PARANÁ RIVER (ARGENTINA AND PARAGUAY)
}

\author{
NEIFF, J. J., ${ }^{1}$ POI DE NEIFF, A. S. G., ${ }^{2}$ PATIÑO, C. A. E. ${ }^{3}$ and \\ BASTERRA DE CHIOZZI, I. ${ }^{4}$ \\ ${ }^{1}$ Centro de Ecología Aplicada, Consejo Nacional de Investigaciones Científicas y Técnicas, Casilla de Correo 222 , \\ Corrientes (3400), Argentina \\ ${ }^{2}$ Facultad de Ciencias Exactas, Naturales y Agrimensura, Universidad Nacional del Nordeste y Centro de Ecología \\ Aplicada del Litoral, Consejo Nacional de Investigaciones Científicas y Técnicas de Argentina, Casilla de Correo \\ 291, Corrientes (3400), Argentina \\ ${ }^{3}$ Centro de Ecología Aplicada, Consejo Nacional de Investigaciones Científicas y Técnicas y Universidad Nacional \\ de Formosa. Casilla de Correo 291, Corrientes (3400), Argentina \\ ${ }^{4}$ Facultad de Ingeniería, Universidad Nacional del Nordeste, Las Heras 727, Resistencia (3500), Chaco, Argentina \\ Correspondence to: Juan Jose Neiff, Centro de Ecología Aplicada, Consejo Nacional de Investigaciones Científicas \\ y Técnicas, Casilla de Correo 222, Corrientes (3400), Argentina, e-mail: neiff@arnet.com.ar \\ Received June 22, 1999 - Accepted September 29, 1999 - Distributed November 30, 2000
}

(With 7 figures)

\begin{abstract}
The potential colonization by anchored plants (PCAP) and the potential areas for initial colonization of free floating plants were estimated during the early filling phase for the Yaciretá reservoir. In order to obtain the PCAP, the observed maximum depth of colonization of the anchored macrophytes before impoundment and the hypsographic curves were used. The species inhabiting the preimpoundment area were classified according to the different bioforms before the inclussion in the analysis. The areal extent of PCAP (from depths between 0-4 m) could reach $275 \mathrm{~km}^{2}$ at $76 \mathrm{~m}$ above sea level (current water level), whereas at $82 \mathrm{~m}$ above sea level (final filling level) the littoral zone will be increased by about $21.5 \%$. The potential area for geophytes was estimated to be $99 \mathrm{~km}^{2} ; 131 \mathrm{~km}^{2}$ for root-floating leaved plants and $120 \mathrm{~km}^{2}$ for submerged plants, at $76 \mathrm{~m}$ above sea level. At $82 \mathrm{~m}$ above sea level, the geophytes could reach $271 \mathrm{~km}^{2}$. The data for wind frequency, velocity and fetch, together with depth were used to calculate shallow and sheltered areas in which free floating plants could find favourable conditions to initial colonization. Physical and chemical features recorded at eight stations during the early filling phase are discussed in relation to potential plant development.
\end{abstract}

Key words: tropical rivers, impounding reservoirs, South America, potential macrophytes colonization, reservoirs.

\section{RESUMO}

\section{Predição da colonização por macrófitas no reservatório de Yaciretá do Rio Paraná}

A colonização potencial por plantas enraizadas (CPPE) e as áreas potenciais de colonização por plantas fluentes livres foram calculadas durante a fase de enchimento do reservatório de Yaciretá. Para obter o CPPE, a máxima profundidade de enraizamento observada previa o fechamento do rio e as curvas ipsográficas foram utilizadas. As espécies presentas na área pré-represamento foram classificadas de acordo com as diferentes bioformas antes da inclusão na análise: A extenção de CPPE (para profundidades entre 0-4 m) poderia alcançar $275 \mathrm{~km}^{2}$ a $76 \mathrm{~m}$ acima do nível do mar (nível de água atual), enquanto na cota de $82 \mathrm{~m}$ acima do nível do mar (nível de recheio final) a zona litorânea será aumentada em aproximadamente $21,5 \%$. A área potencial para macróficas emersas foi calculada em $99 \mathrm{~km}^{2}$, para as plantas enraizadas com folhas flutuantes em $131 \mathrm{~km}^{2}$, e para as plantas enraizadas submersas em 
$120 \mathrm{~km}^{2}$, a $76 \mathrm{~m}$ acima do nível do mar. A $82 \mathrm{~m}$ acima do nível do mar, as macrófitas emersas poderiam alcançar $271 \mathrm{~km}^{2}$. A informação de freqüência, velocidade de ventos, e de fetch, junto com dados de profundidade foram usados para delimitar áreas rasas e abrigadas, nas quais plantas flutuantes livres poderiam encontrar condições favoráveis para iniciar a colonização. As características físicas e químicas obtidas em oito estações de amostragem no início da formação do reservatório são discutidas em relação ao desenvolvimento potencial das macrófitas.

Palavras-chave: reservatórios, rios tropicais, colonização potencial por macrófitas, barragens, América do Sul.

\section{INTRODUCTION}

Yaciretá is a new man-made lake located on the High Paraná River $\left(27^{\circ} 11^{\prime}\right.$ S; $\left.56^{\circ} 20^{\prime} \mathrm{W}\right)$, near Ituzaingó (Argentina) and Ayolas (Paraguay), which started operating in September 1994. Its main morphometric characteristics are: length of $66.5 \mathrm{~km}$; surface area of $1.600 \mathrm{~km}^{2}$ at $82 \mathrm{~m}$ above sea level; volume of $21,000 \mathrm{hm}^{3}$; maximum depth of $30 \mathrm{~m}$. Compared with other reservoirs built on the Paraná River (Tundisi et al., 1993) its retention time is short ( $<20$ days). The lake area, which was mainly covered by various types of forests, swamps, ponds and peatland soils, was deficiently cleared before the dam was closed. At the moment, Yaciretá is in the first step of the filling phase (actual water level: $76 \mathrm{~m}$ above sea level), leading to a planned $82 \mathrm{~m}$ above sea level in the future.

Several small tributaries (minor than 60 $\mathrm{m}^{3} \cdot \mathrm{s}^{-1}$ ) feed the reservoir, but the most important are Garupá, Itaembé and Tacuarí stream.

The objective of this study was to estimate potential areas of the dam that the anchored plants (PCAP) could colonize. The observed maximum depth of colonization of macrophytes presents in the area before the impoundment and the hypsographic curves were used in this procedure.

A second objective was to estimate potential areas for the initial colonization for floating plants starting from the morphometry of the reservoir and the predominant winds. The possible development of these plants was analyzed in function of the physical and chemical characteristics registered during the early filling phase of the reservoir.

\section{Limnological data from the High Paraná River prior to the Yaciretá impoundment}

Based on the published data available (Varela et al., 1983; Bonetto, 1986; Bonetto \& Lancelle,
1981), the water of the Higher Paraná River was characterized by a high turbidity and colour during floods (Secchi disk $\cong 0.8 \mathrm{~m}$ ), but these parameters drop when the flow becomes low (Secchi disk $\cong$ $1.30 \mathrm{~m})$. Maximum water temperature $\left(30^{\circ} \mathrm{C}\right)$ is reached in February. Then, the temperature decreases to a minimum $\left(15^{\circ} \mathrm{C}\right)$ in late July. The Paraná River surface water is generally well supplied with dissolved oxygen, with values near saturation. The $\mathrm{pH}$ tends to be neutral ranging from 7-7.5. The average ionic composition by equivalents indicates the overall importance of bicarbonate calcium and magnesium. Conductivity shows a relationship with the flow regime but remains near $100 \mu \mathrm{Scm}^{-1}$.

The lotic environments of the High Paraná are relatively low in species richness and abundance of aquatic plants (Neiff, 1986a), due to high current velocities, steep banks and a deep channel of variable width. Podostemaceae occur only in the areas of rapids, where they tolerate current speeds of 2-3 $\mathrm{m} \cdot \mathrm{s}^{-1}$.

Downstream of Puerto Candelaria (Fig. 1) the river originates several islands of $5-20 \mathrm{~km}^{2}$ area which are $15 \mathrm{~m}$ above the mean water level. Only the High parts of the Yaciretá islands remain emerged now after the impoundment. Other areas, such as the Talavera island and the lower parts of the Yaciretá islands, with extensive regions of swamps and peatlands, were covered by waters.

The landscape units and vegetation of the river tract before the Yaciretá reservoir were described by Neiff (1986a, 1986b), and Cuadrado \& Neiff (1993). The dominant macrophytes in the lake and wetlands before impoundment depend on the frequency and duration of the river pulses (Neiff, 1996). In periodically inundated lakes, the dominant bioforms are free-floating plants ( $E i$ chhornia crassipes, Pistia stratiotes and Salvinia 
spp.), while the geophytes (Cyperus giganteus, Typha latifolia, Thalia multiflora) are dominant in swamp and lake areas coupled sporadically by the river dynamics, reaching a height of $2.5 \mathrm{~m}$ and developing a continuous canopy for several $\mathrm{km}$.
Aquatic submerged plants, such as Ceratophyllum demersum, Najas marina, Utricularia foliosa and Cabomba australis, and root-floating leaved plants (Nymphoides indica, Victoria cruziana) are dominant in island ponds with soft bottom sediments.

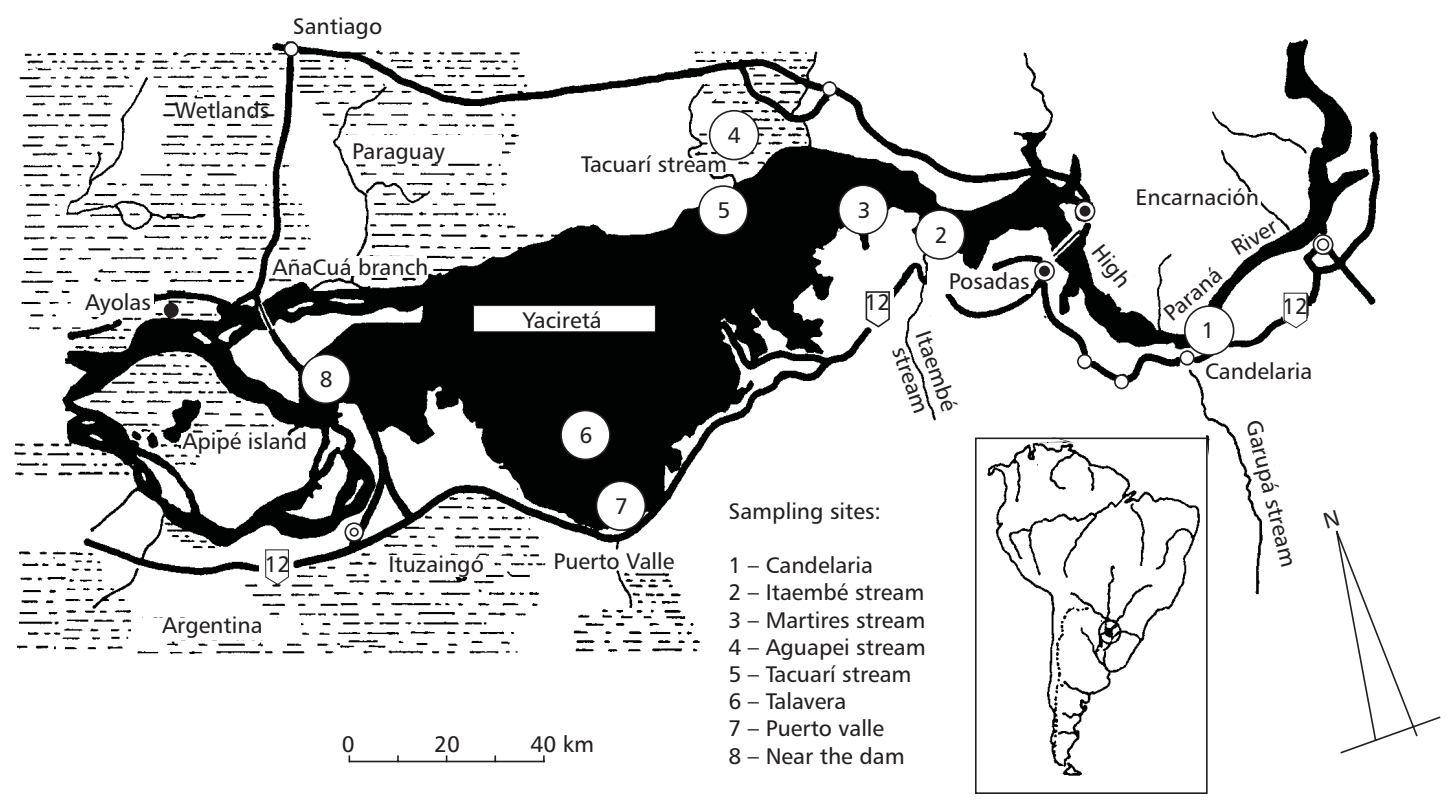

Fig. 1 - Location of the sampling sites in the Yaciretá dam and high Paraná River.

Pioneer forests on sand banks were dominated by a very dense gallery of Salix humboldtiana, and Croton urucurana was also present. In tall levees, the plurispecific forest reaches 10$12 \mathrm{~m}$ height and $0.9 \mathrm{~m}$ of diameter at breast heigh (DBH), with Nectandra membranacea var. falcifolia, Ocotea acutifolia and Myrceugenella apiculata as the more frequent species. The high position of the topographic gradient is occupied by a tall forest of up to 15-20 m, with 18 tree species (Piptadenia macrocarpa, Tabebuia ipe and Peltophorum vogelianum, among others).

\section{METHODS}

In order to obtain the potential areal colonization by anchored plants (PCAP), the macrophytes inhabiting the Yaciretá preimpoundment area (Neiff, 1986a, 1986b) were classified accor- ding to the different bioforms. For each bioform, maximum and minimum depth in which the plant grew, were defined.

The potential areal extent of the littoral zone in which the rooted plants could colonize depends on two morphometric features of the lake: the shore development, which is the relationship between the shoreline of the lake and its area, compared with the circumference of a circle that has the same area as the lake, and the slope of the shore. Both were obtained directly using a Kontron planimeter.

The flooded areas at different depths were computed using the Geographic Information System IDRISI (Fig. 2).

Based on the planimetry, hypsographic curves of the lake surface were plotted and the Digital Elevation Model (DEM) was obtained. After a field survey of the reservoir was done, map curves were adjusted. 


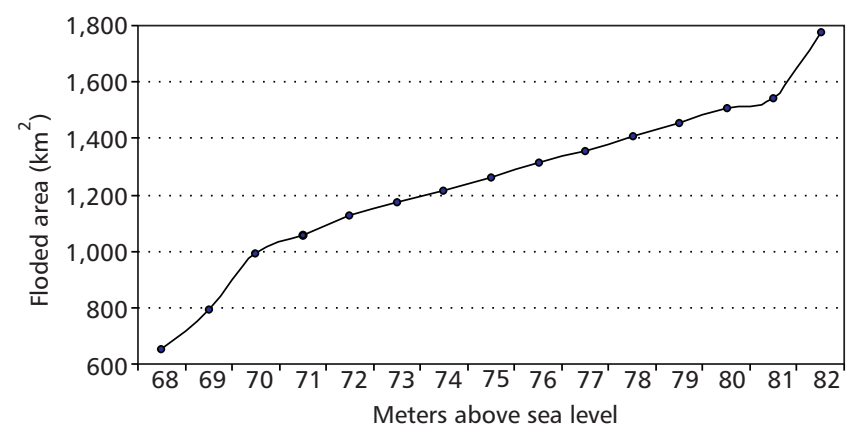

Fig. 2 - Flooded area between 68 and $82 \mathrm{~m}$ above sea level during filling phase.

To know if the physical and chemical conditions of the water could favour the macrophytes grow, the following environmental parameters were recorded: water temperature; electric conductivity; dissolved oxygen (in profiles); transparency (measured using a Secchi disk); chemical parameters $[\mathrm{pH}$, ionic concentration, nutrient concentration (nitrate + nitrite, ammonia, total phosphorus)].

Water samples were collected for eight stations (Fig. 1) between July 1994 and January 1995 (early filling phase). Station 1 was located on the High Paraná River above the Yaciretá reservoir. Stations 2, 3, 4 and 5 were placed at the mouths of the tributaries. Station 6 was located over the oldest Talavera island. Station 7 was greatly influenced by winds, and Station 8 was placed in the lake near the dam.

Climatological data (Fig. 3), collected between 1960 and 1995, were provided by a meteorological station located in Ituzaingó City, on the right bank of the impoundment. The potential effect of the wind on the water surface was estimated from satellite images, considering the frequency and velocity of the wind and the distance over which the wind had blown without being interrupted by land (fetch).

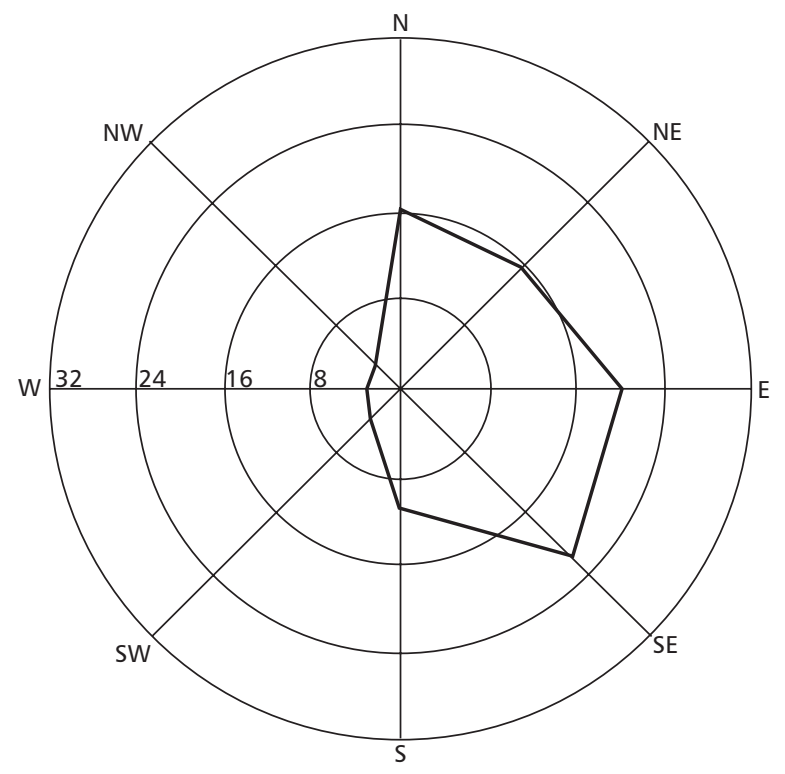

Fig. 3 - Annual mean frequency of the wind at Ituzaingó Station. 
We also defined accumulation areas as sites in which the wind tends to gather the plants together (e. g. free-floating and sudd hydrophytes). These zones are important because a quick succession could produce true floating islands in the lakes existing before the filling of the Yaciretá reservoir in a very short time (Neiff, 1986a, 1986b; Cuadrado \& Neiff, 1993).

\section{RESULTS}

From the planimetric map, the form index (ratio between the area of the reservoir and its perimeter) was similar to 0.2 in both filling phases (76 and $82 \mathrm{~m}$ above sea level).

Fluctuation in the water level of the lake was expected to be of small amplitude $(<1.5 \mathrm{~m})$, compared to the Paraná River before the impoundment ( $5 \mathrm{~m}$ in Puerto Posadas, Argentina).

The main physical and chemical characteristics of the water during the early filling phase are summarized in Table 1.

During the study period, the hydrological regime of the High Paraná River was characterized by floods in July - September 1994 and low water phases in January 1995. The river water turbidity was most pronounced during flood (Table 1B), at which time the Secchi disk dropped to about 0.35 $\mathrm{m}$. At low waters there was an increase in the transparency (Secchi disk 0.7-1.9 m).

Initial deoxygenation of the lake was much less pronounced than that expected from information from other tropical reservoirs (Van der Lingen, 1973; Van der Heide, 1982; Barrow, 1987; Junk \& de Mello, 1987; Tundisi et al., 1993) and oxygen concentrations on the water surface never dropped below $63 \%$ saturation (Table 1). However, during stratification, deoxygenation of water occurred at lacustrine regions, and oxygen concentrations in the lower layer dropped to $<1 \mathrm{mg}$. $\mathrm{L}^{-1}$. Surface concentrations remained below $15 \%$ saturation (Table 1)

The total mineral content of surface waters was low. At the sampling sites, conductivity ranged from 39 to $75 \mu \mathrm{S} . \mathrm{cm}^{-1}$. The average ionic composition was characteristic of calcium-bicarbonated waters. The order of dominance for cations and anions was similar to that of the river prior to the impoundment. However, potassium was an exception, reaching relatively high concentrations at
Stations 2, 3 and 6 during September. Concentrations of nitrogen (nitrate + nitrite) and total phosphorus in the water were low (Table 1).

The water temperature (Table 1), of the lake, recorded at different stations, oscilated between $17.7^{\circ} \mathrm{C}$ (winter) and $29.5^{\circ} \mathrm{C}$ (summer).

\section{Potential areal colonization by anchored plants (PCAP)}

There were no geophytes (Typha spp., Scirpus californicus) which could colonize the preimpoundment area below $1.5 \mathrm{~m}$ depth, and the root-floating leaved plants (Victoria cruziana, Nymphaea spp., Nymphoides indica) were found until a depth boundary of $3.5 \mathrm{~m}$. In order to include the annual water fluctuation, half meters were added in both cases. So, the boundary of the geophytes potential zone was established at $2 \mathrm{~m}$ depth, and the root-floating leaved plants potential zone, at $4 \mathrm{~m}$ depth (Table 2). In the lakes of islands prior the Yaciretá impoundment the submersed plants usually grow to depths of less than four meters (Table 2). This depth was taken as maximum depth for the colonization for submerged plants.

Therefore, the potential areal colonization by anchored plants (PCAP) included the portion of the litoral zones that comprehended 0-4 $\mathrm{m}$ of depth. The areal extent of this reach 275 and $350 \mathrm{~km}^{2}$ at 76 and $82 \mathrm{~m}$ above sea level respectively. The potential area for Geophytes was estimated to be $99 \mathrm{~km}^{2} ; 131 \mathrm{~km}^{2}$ for root-floating leaved plants and $120 \mathrm{~km}^{2}$ for submerged plants, at $76 \mathrm{~m}$ above sea level (current water level). At $82 \mathrm{~m}$ above sea level (final water level), the potential area colonized by geophytes could reach $271 \mathrm{~km}^{2}$ (Table 3 ).

The bottom of the lake has lime/clay sediments in the shore line with $8 \%$ of organic matter (Paggi et al., 1998). Except in the Station 8, which has emergent basaltic blocks as substrate, there are not restrictions for the rooting of the macrophytes in the shore line.

\section{Estimation of areas for initial colonization by free floating plants}

Prevailing winds are of considerable importance to calculate the extent and position of these areas. Easterly (NE-E-SE) constant winds of 40 to $60 \mathrm{~km} / \mathrm{h}$ were the most frequently found (Fig. 3 ). During winter and springtime, south and southeasterly winds reached $90 \mathrm{~km} / \mathrm{h}$ during storms. 
TABLE 1

Physico-chemical characterization of the surface water at eigth sampling sites in Yaciretá dam during the early filling phase.

\begin{tabular}{|c|c|c|c|c|c|c|c|}
\hline \multicolumn{4}{|c|}{ A: High Paraná River at low water } & \multicolumn{4}{|c|}{ B: High Paraná River at high water } \\
\hline \multicolumn{8}{|l|}{ A } \\
\hline & $\begin{array}{c}\text { Station 1 } \\
(\text { July, 1994) } \\
\end{array}$ & $\begin{array}{c}\text { Station } 2 \\
(\text { Sep., 1994) } \\
\end{array}$ & $\begin{array}{c}\text { Station } 3 \\
\text { (Sep., 1994) } \\
\end{array}$ & $\begin{array}{c}\text { Station } 4 \\
\text { (July, 1994) } \\
\end{array}$ & $\begin{array}{c}\text { Station } 6 \\
\text { (Sep., 1994) } \\
\end{array}$ & $\begin{array}{c}\text { Station } 7 \\
\text { (July, 1994) }\end{array}$ & $\begin{array}{c}\text { Station } 8 \\
\text { (July, 1994) }\end{array}$ \\
\hline Water temperature $\left({ }^{\circ} \mathrm{C}\right)$ & 18 & 18.2 & 20 & 19 & 20 & 18 & 17.7 \\
\hline $\begin{array}{l}\text { Dissolved oxygen } \\
\left(\mathrm{mg} . \mathrm{L}^{-1}\right)\end{array}$ & 9.8 & 6.5 & 7.2 & 9.2 & 6.2 & 8.8 & 8.2 \\
\hline Conductivity $\left(\mu \mathrm{S} . \mathrm{cm}^{-1}\right)$ & 45 & 42 & 70 & 53 & 39 & 40 & 45 \\
\hline $\mathrm{pH}$ & 7.1 & 6.5 & 7 & 5.6 & 7.1 & 7.2 & 7 \\
\hline $\mathrm{HCO}_{3}{ }^{-}\left(\mathrm{mg} \cdot \mathrm{L}^{-1}\right)$ & 21.5 & 18 & 20 & 20 & 19 & 21 & 21 \\
\hline $\mathrm{Ca}^{2+}\left(\mathrm{mg} \cdot \mathrm{L}^{-1}\right)$ & 4 & 1.8 & 2.1 & 1.8 & 1.9 & 3.9 & 4.4 \\
\hline $\mathrm{Mg}^{2+}\left(\mathrm{mg} \cdot \mathrm{L}^{-1}\right)$ & 1.5 & 1.5 & 1.5 & 1.4 & 1.5 & 1.2 & 1.9 \\
\hline $\mathrm{Cl}^{-}\left(\mathrm{mg} \cdot \mathrm{L}^{-1}\right)$ & 1.9 & 1.8 & 2 & 2.5 & 1.8 & 2 & 2.2 \\
\hline $\mathrm{Na}^{+}\left(\mathrm{mg} . \mathrm{L}^{-1}\right)$ & 0.87 & 1.9 & 2.2 & - & 2 & 0.83 & 0.87 \\
\hline $\mathrm{K}^{+}\left(\mathrm{mg} . \mathrm{L}^{-1}\right)$ & 0.5 & 3.5 & 3.5 & - & 3.5 & 0.5 & 0.6 \\
\hline $\mathrm{SO}_{4}{ }^{2-}\left(\mathrm{mg} . \mathrm{L}^{-1}\right)$ & 0.3 & 3.5 & 3.5 & 0.3 & 3.5 & 0.3 & 0.3 \\
\hline $\mathrm{NO}_{3}^{-}+\mathrm{NO}_{2}^{-}\left(\mu \mathrm{g} \cdot \mathrm{L}^{-1}\right)$ & 405 & 75 & 165 & 75 & 215 & 405 & 390 \\
\hline $\mathrm{NH}_{4}^{+}\left(\mu \mathrm{g} . \mathrm{L}^{-1}\right)$ & no det. & 20 & 20 & 33 & 10 & 14 & 14 \\
\hline $\mathrm{P}$ total $\left(\mu \mathrm{g} \cdot \mathrm{L}^{-1}\right)$ & 44 & 20 & 18 & 20 & 16 & 44 & 44 \\
\hline Secchi disk $(\mathrm{cm})$ & 98 & 70 & 70 & - & 70 & 90 & 92 \\
\hline \multicolumn{8}{|l|}{ B } \\
\hline & $\begin{array}{c}\text { Station 1 } \\
(\text { Jan., 1995) }\end{array}$ & $\begin{array}{c}\text { Station 2 } \\
(\text { Jan., 1995) }\end{array}$ & $\begin{array}{c}\text { Station } 4 \\
(\text { Jan., 1995) }\end{array}$ & $\begin{array}{c}\text { Station 5 } \\
(\text { Jan., 1995) }\end{array}$ & $\begin{array}{c}\text { Station 6 } \\
\left(J^{2} ., 1995\right)\end{array}$ & $\begin{array}{c}\text { Station } 7 \\
(\text { Jan., 1995) }\end{array}$ & $\begin{array}{c}\text { Station } 8 \\
(\text { Jan., 1995) }\end{array}$ \\
\hline Water temperature $\left({ }^{\circ} \mathrm{C}\right)$ & 27 & 29.5 & 26.5 & 27 & 28.5 & 28 & 28 \\
\hline $\begin{array}{l}\text { Dissolved oxygen } \\
\left(\mathrm{mg} \cdot \mathrm{L}^{-1}\right)\end{array}$ & 8.7 & 4.8 & 8.5 & 8.2 & 7.4 & 7.7 & 7.9 \\
\hline Conductivity $\left(\mu \mathrm{S} . \mathrm{cm}^{-1}\right)$ & 54 & 60 & 50 & 50 & 59 & 47 & 49 \\
\hline $\mathrm{PH}$ & 7.4 & 6.5 & 6 & 6 & 7.3 & 7 & 7.2 \\
\hline $\mathrm{HCO}_{3}{ }^{-}\left(\mathrm{mg} \cdot \mathrm{L}^{-1}\right)$ & 23 & - & - & - & - & 20 & 20 \\
\hline $\mathrm{Ca}^{2+}\left(\mathrm{mg} \cdot \mathrm{L}^{-1}\right)$ & 4.28 & - & - & - & - & 4.06 & 4.28 \\
\hline $\mathrm{Mg}^{2+}\left(\mathrm{mg} \cdot \mathrm{L}^{-1}\right)$ & 1.56 & - & - & - & - & 1.43 & 1.30 \\
\hline $\mathrm{Cl}^{-}\left(\mathrm{mg} \cdot \mathrm{L}^{-1}\right)$ & 2.5 & - & - & - & - & 2.5 & 2.4 \\
\hline $\mathrm{Na}^{+}\left(\mathrm{mg} . \mathrm{L}^{-1}\right)$ & 0.8 & - & - & - & - & 0.8 & 0.8 \\
\hline $\mathrm{K}^{+}\left(\mathrm{mg} \cdot \mathrm{L}^{-1}\right)$ & 0.5 & - & - & - & - & 0.6 & 0.6 \\
\hline $\mathrm{SO}_{4}{ }^{2-}\left(\mathrm{mg} \cdot \mathrm{L}^{-1}\right)$ & 0.3 & - & - & - & - & 0.3 & 0.3 \\
\hline $\mathrm{NO}_{3}{ }^{-}+\mathrm{NO}_{2}^{-}\left(\mu \mathrm{g} \cdot \mathrm{L}^{-1}\right)$ & 196 & - & 315 & 358 & 352 & 114 & 103 \\
\hline $\mathrm{NH}_{4}^{+}\left(\mu \mathrm{g} . \mathrm{L}^{-1}\right)$ & 58 & 10 & 8 & 8 & 10 & 39 & 52 \\
\hline$P$ total $\left(\mu \mathrm{g} . \mathrm{L}^{-1}\right)$ & 48 & 47 & 47 & 46 & 43 & 46 & 40 \\
\hline Secchi disk $(\mathrm{cm})$ & 35 & 35 & 30 & 30 & 35 & - & - \\
\hline
\end{tabular}


TABLE 2

Plants inhabiting lenthic and lotic environments in the preimpoundment area. The observation points in which the species were registered are mentioned in the right column.

\begin{tabular}{|c|c|c|c|c|c|c|}
\hline \multirow{2}{*}{$\begin{array}{l}\text { Bioforms } \\
\text { A: Anchored plants } \\
\text { A-1: Geophytes }\end{array}$} & \multicolumn{4}{|c|}{ Depth (in meters) } & \multirow{2}{*}{$\begin{array}{l}\text { > Frequency } \\
\text { in a belt of: }\end{array}$} & \multirow{2}{*}{ Sites } \\
\hline & $0-0.5-1$ & 1-1.5-2 & $2-2.5-3$ & $3.5-4-4.5$ & & \\
\hline Typha latifolia $(*)$ & --------- & --------- & -- & & $0.5-1.5$ & 2,4 \\
\hline $\begin{array}{l}\text { Schoenoplectus californicus } \\
\text { californicus }\end{array}$ & ---------- & ------- - & - & & $0.0-1.2$ & 5 \\
\hline Cyperus giganteus & 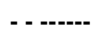 & -- & & & $0.5-1.0$ & 4,5 \\
\hline Thalia geniculata & ---- - - & -- & & & $0.2-0.9$ & 4 \\
\hline Thalia multiflora & ----- - & $\ldots$ & & & $0.3-0.9$ & 4 \\
\hline Sagittaria montevidensis & ---- - - & - & & & $0.0-0.8$ & $2,3,7$ \\
\hline Pontederia lanceolata & --- & & & & $0.1-0.5$ & $2,3,7$ \\
\hline Bacopa sp. & -- & & & & $0.0-0.1$ & 7 \\
\hline Enhydra anagallis & - - ---- & -- & & & $0.3-1.0$ & 4,5 \\
\hline Echinochloa helodes $(*)$ & ---- - - & & & & $0.5-1.0$ & 2 \\
\hline Panicum grumosum & - & 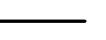 & & & $0.5-1.5$ & 2,5 \\
\hline Paspalum repens $(*)$ & --------- & --------- & & & $1.0-2.0$ & $1,2,3,7$ \\
\hline Polygonum punctatum & --------- & $\ldots$ & & & $0.1-1.0$ & $2,3,5,7$ \\
\hline P. acuminatum & $-\cdots$ & $-\ldots$ & $\ldots$ & & $0.5-1.2$ & $4,5,7$ \\
\hline $\begin{array}{l}\text { Althernanthera } \\
\text { phyloxeroides }\end{array}$ & - --- - & -- & & & $0.3-1.0$ & 2,7 \\
\hline Hymenachne amplexicaulis & $\longrightarrow$ & & & & $0.1-0.5$ & 4,5 \\
\hline \multicolumn{7}{|l|}{ A-2: Floating leaved plants } \\
\hline Nymphaea amazonum & - & -------- & ------ - & - & $1.0-2.5$ & 2,3 \\
\hline Nymphoides indica & --- & --------- & |-------- & - & $1.5-2.8$ & 3,5 \\
\hline Hydrocleis nymphoides & - --- - & & & & $0.2-0.6$ & 2 \\
\hline Myriophyllum brasiliense & - ---- & $-\cdots$ & & & $0.6-1.3$ & 3,4 \\
\hline Eichhornia azurea & ---- & --------- & 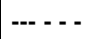 & - & & $2,3,4,5,7$ \\
\hline Ludwigia peploides & -------- & ------- & -... - & - & $1.0-2.5$ & $2,3,4,5,7$ \\
\hline \multicolumn{7}{|l|}{ A-3: Submerged plants } \\
\hline Potamogeton berteroanus & - & $-\cdots$ & $\ldots$ & & $1.3-2.5$ & $2,3,4,5,7$ \\
\hline Potamogeton pectinatus & & - - - - - - & $-\cdots$ & & $1.5-2.5$ & $2,3,4,5,7$ \\
\hline Cabomba australis & & $-\cdots$ & -- ------ & ------ - & $1.5-3.0$ & 5 \\
\hline Egeria naias & & - & - - - - & --------- & $2.0-4.0$ & 5 \\
\hline Nitella sp. & & -- & ------ - & $\ldots \ldots$ & $1.2-2.1$ & 5 \\
\hline \multicolumn{7}{|l|}{$\begin{array}{l}\text { B: Free plants } \\
\text { B-1: Floating plants }\end{array}$} \\
\hline $\begin{array}{l}\text { Spirodella intermedia } \\
\text { Lemna spp. }\end{array}$ & & & & & wide range & $4,5,7$ \\
\hline
\end{tabular}

— line indicates the depth range for the species in lakes and rivers near the Yaciretá dam (record = 66 environments since 1980).

------ = abundant

- - - = scarce.

Sites: 1-8 are the observation points in the Yaciretá basin (see: Fig. 1). 
TABLE 2 (Continued)

\begin{tabular}{|c|c|c|c|c|c|}
\hline Bioforms & Depth (in meters) & & & $>$ Frequency & Sites \\
\hline Ricciocarpus natans & & & & Wide Range & $4,5,7$ \\
\hline Azolla caroliniana & & & & Wide Range & 4,5 \\
\hline Salvinia herzogii & & & & Wide Range & 3,7 \\
\hline Pistia stratiotes & & & & Wide Range & $2,3,4,7$ \\
\hline Limnobium laevigatum & & & & Wide Range & 2,4 \\
\hline Eichhornia crassipes & & & & Wide Range & $2,3,4,5$ \\
\hline B-2: Submerged plants & & & & & \\
\hline Utricularia foliosa & $\ldots$ & --.-- - & - & $2.0-3.0$ & 4 \\
\hline $\begin{array}{l}\text { C: Epiphytes (growing over } \\
\text { other plants) }\end{array}$ & & & & $\begin{array}{l}\text { not related to } \\
\text { depth }\end{array}$ & \\
\hline $\begin{array}{l}\text { Spp. With }\left(^{*}\right) \text { in A-1 (see } \\
\text { above) }\end{array}$ & & & & $\begin{array}{l}\text { not related to } \\
\text { depth }\end{array}$ & \\
\hline Hydrocotyle ranunculoides & & & & $\begin{array}{l}\text { not related to } \\
\text { depth }\end{array}$ & $3,4,57$ \\
\hline Ludwigia repens & & & & $\begin{array}{l}\text { not related to } \\
\text { depth }\end{array}$ & 3,5 \\
\hline $\begin{array}{l}\text { Scirpus cubensis var. } \\
\text { paraguaayensis }\end{array}$ & & & & $\begin{array}{l}\text { not related to } \\
\text { depth }\end{array}$ & $2,3,4,5,7$ \\
\hline Bidens laevis & & & & $\begin{array}{l}\text { not related to } \\
\text { depth }\end{array}$ & 4,5 \\
\hline Senecio bonariensis & & & & $\begin{array}{l}\text { not related to } \\
\text { depth }\end{array}$ & 5 \\
\hline
\end{tabular}

— indicates the depth range for the species in lakes and rivers near the Yaciretá dam (record = 66 environments since 1980).

------ = abundant.

- - - = scarce.

Sites: 1-8 are the observation points in the Yaciretá basin (see: Fig. 1).

TABLE 3

Potential areas that could be occupied for different bioforms after two philling phases.

\begin{tabular}{|l|c|c|c|c|}
\hline \multicolumn{1}{|c|}{ Bioforms } & Depth range $(\mathbf{m})$ & $\mathbf{7 6} \mathbf{~ m}$ above sea level $\left(\mathbf{k m}^{\mathbf{2}}\right)$ & $\mathbf{8 2} \mathbf{~ m}$ above sea level $\left(\mathbf{k m}^{\mathbf{2}}\right)$ & Area 82-76 \\
\hline Geophytes & $0.2-2.0$ & 99 & 271 & +172 \\
\hline Root leaved & $1.0-4.0$ & 131 & 134 & +3 \\
\hline Submerged & $1.5-4.0$ & 120 & 105 & -15 \\
\hline PCAP & $\mathbf{0 - 4 . 0}$ & $\mathbf{2 7 5}$ & $\mathbf{3 5 0}$ & +75 \\
\hline
\end{tabular}

With values of fetch less than four kilometers and depth less than two meters, we estimated the areas comprissed in the Figs. 5, 6 and 7 for predominant winds.

These areas reach $25.12 \mathrm{~km}^{2}$ for predominant winds of southeast and $18.34 \mathrm{~km}^{2}$ for northeast winds at water elevation of $76 \mathrm{~m}$ above the sea level (Fig. 5). With the reservoir at water elevation of $82 \mathrm{~m}$ above sea level, the areas for initial colo- nization (Figs. 6 and 7) were estimated to be of $54.5 \mathrm{~km}^{2}$ for winds of the southeast and of $79.7 \mathrm{~km}^{2}$ for winds of the northeast. Considering the velocity and duration of the more frequent winds and the coincidence between them and the flow of the water circulation in the reservoir $(\mathrm{E}-\mathrm{W})$, the displacement of the whole floating body will tend to concentrate in the sectors comprised between Stations 7 and 8 , considered as accumulation areas. 

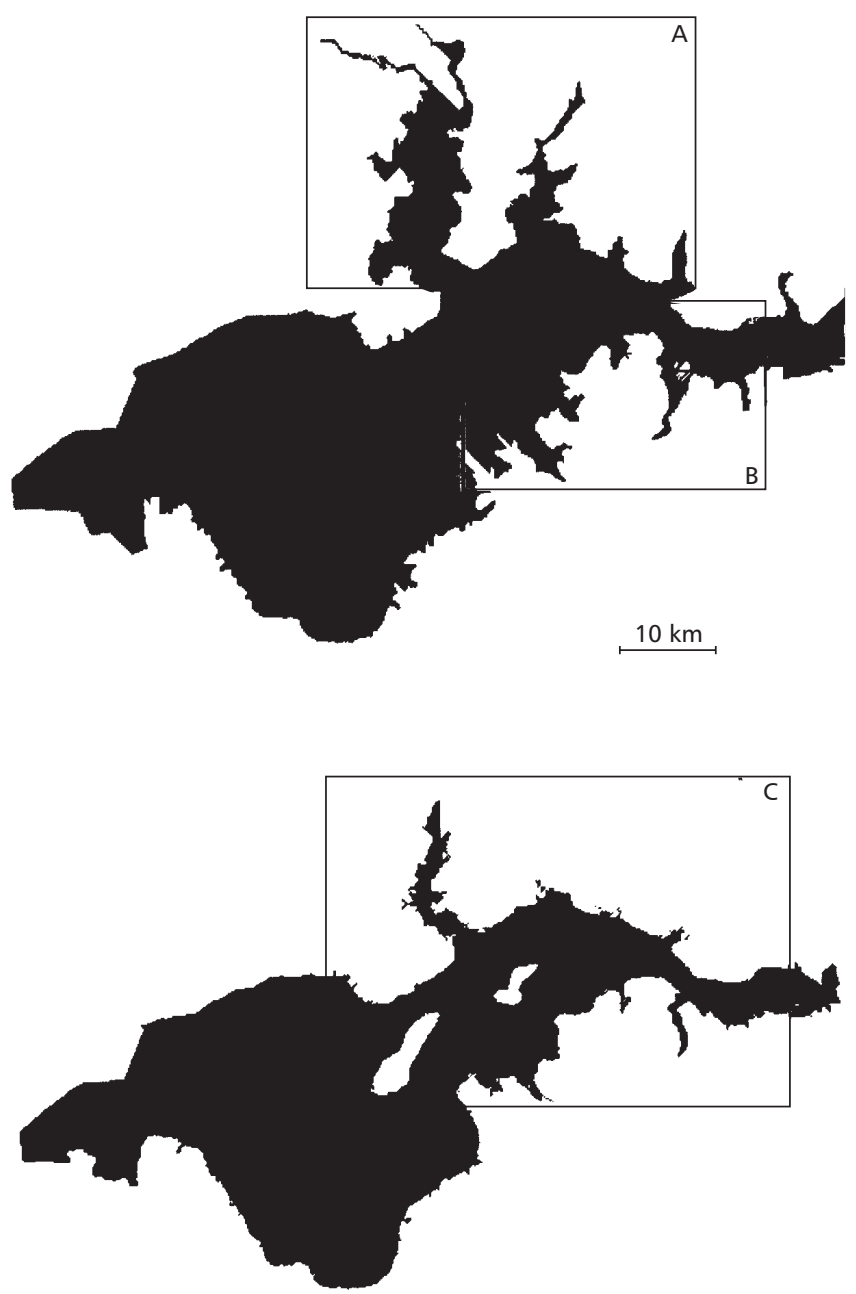

Fig. 4 - Sectors at Yaciretá dam processed with IDRISI to calculate potential areas for free floating plants development.

No significant input of free-floating plants should be expected from the tributaries of the Yaciretá reservoir because of the physiography of its basins (including the High Paraná River). However, these inputs are important as "seedings" in the areas for initial colonization.

\section{Final remarks}

The observed maximum depth of anchored plants in a pre-impoundment conditions should provide a reasonable estimate of the areal extent of the zone that different bioforms of macrophytes could be colonized. The results found in this study allow as to conclude that the area occupied by the littoral zone will be increased by $21.5 \%$ at the end of the filling phase (water elevation of $82 \mathrm{~m}$ above sea level). In this way, the geophytes would occupy an area proportionally more extensive than other bioforms of plants due to the increase in shallow waters at this water elevation.

Since the maximum depth of colonization by aquatic submersed macrophytes depend on the changes in the transparency, the calculated areas will be adjusted by employing a predictive model developed by Canfield et al. (1985) that involves the Secchi disk reading. With the current values of transparency (early filling phase), the maximum depth of colonization using Canfield's equation could be reach to $2.5 \mathrm{~m}$. If the transparency remains low for several years, the area colonized by submerged plants would be smaller than the predicted for observed maximum depth. 


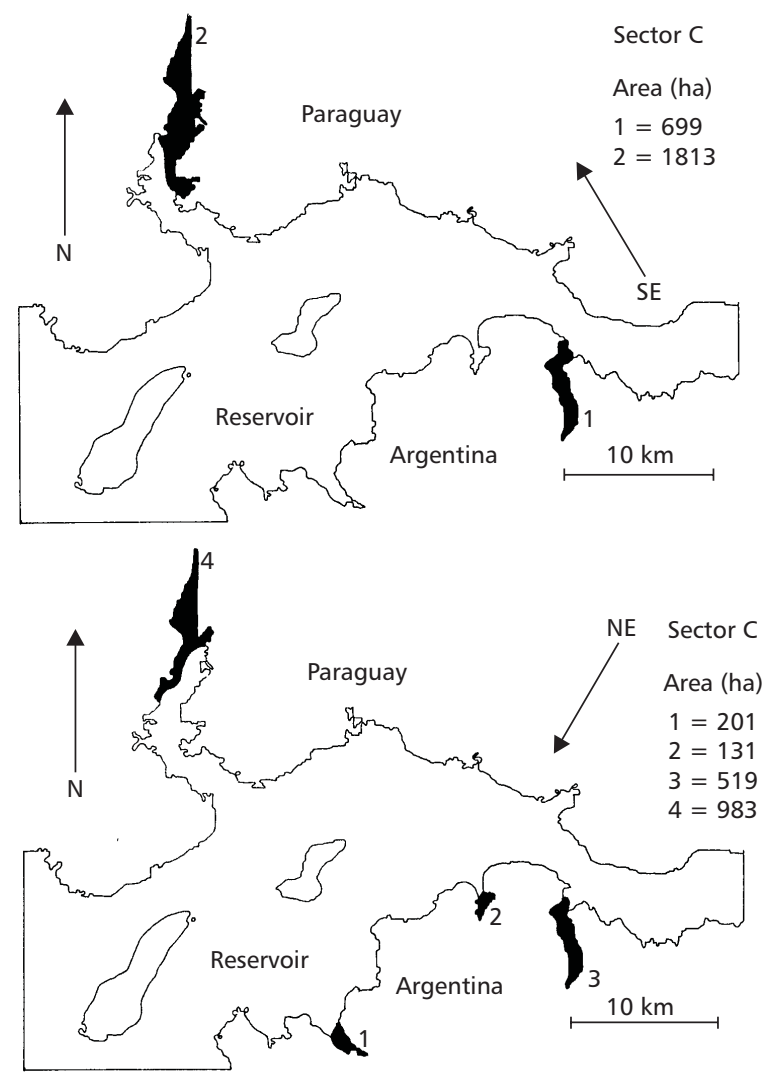

Fig. 5 - Potential areas for initial floating plants colonization for SE (above) and NE (below) prevailing winds. Reservoir at $76 \mathrm{~m}$ a.s. 1 .

If the transparency increase (i. e. Secchi disk value of $1.9 \mathrm{~m}$ ) the maximum depth of colonization estimated by Canfield's equation could be reach $3.36 \mathrm{~m}$, which is very close to the value used in the PCAP prediction.

Colonization of the free floating macrophytes in man-made lakes is related with many variables. Among there were: light, nutrient content, morphometry, wind speed and direction. In the case of Yaciretá reservoir, light and temperature were probably adecuate for free floating plant growth according to the report from african reservoirs (Bond \& Roberts, 1978; Allanson et al., 1990).

Experience in several tropical lakes (Thornton, 1987; Bond \& Roberts, 1978) has indicated a poor correlation between plant growth rates and water nutrients content. Therefore we cannot to discard a possible explosive growth of the populations of floating plants being based only on the low nutrient content in the early filling phase.
In fact, Eichhornia crassipes, Salvinia herzogi, Pistia stratiotes and other free-floating plants were frequently found in the tributaries and several places of the littoral zone. Floodplain lakes enrichment plants (Carignan \& Neiff, 1992) showed that nitrogen is the plant nutrient most likely to limit the growth of Eichhornia crassipes. Therefore, an input of nitrogen could favour the freefloating plant growth. A preventive program is necessary for a rational management of the higher basin, because eutrophication, erosion and other impacts from the marginal cities would probably increase the nitrogen levels in the Yaciretá reservoir favouring, in this way, the plant growth.

But growth rates and quantities of floating plants in a features stages of the lake remain umpredictible. Despite of these, analyses of wind and fetch in relation to morphometry allows usefull predictions of initial points of colonization of plants. 

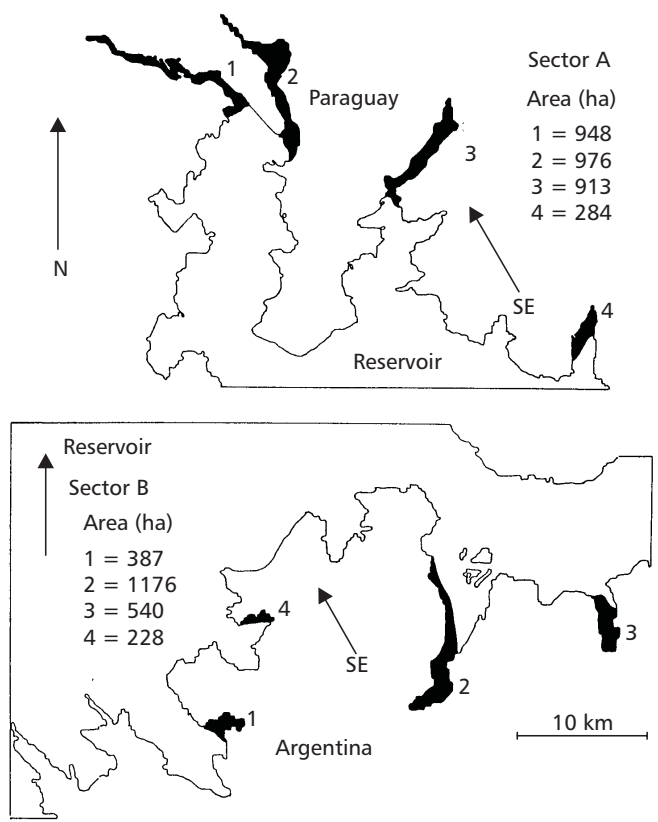

Fig. 6 - Potential areas for initial floating planst colonization for SE prevailing winds. Reservoir at $82 \mathrm{~m}$ a.s. 1.

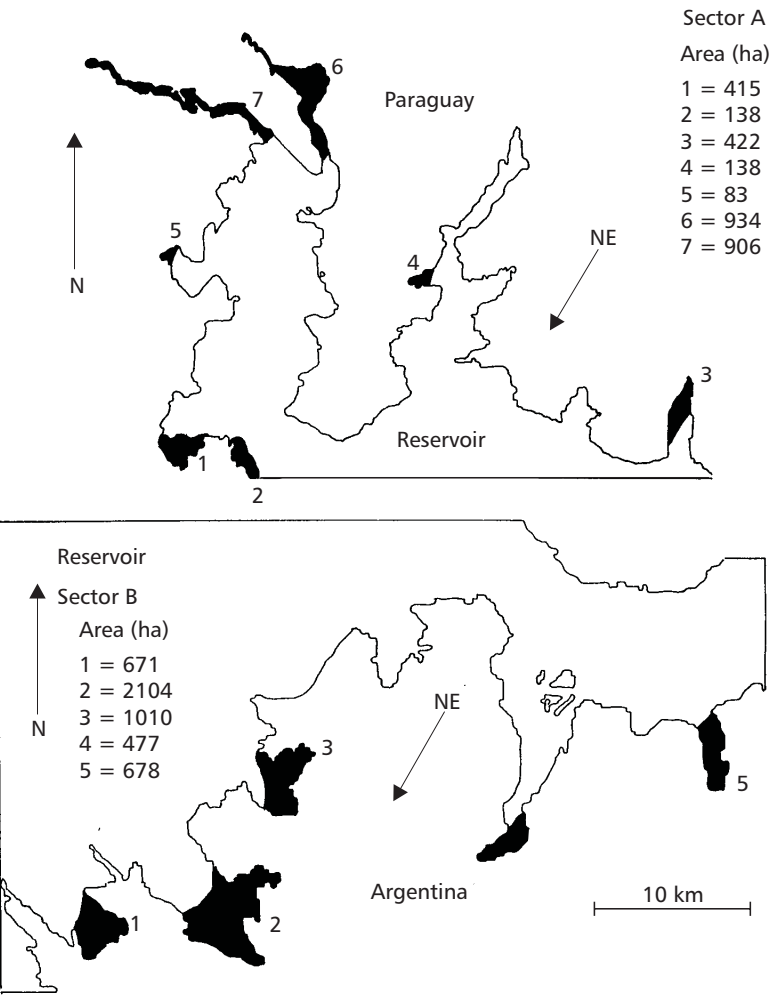

Fig. 7 - Potential areas for initial floating plants colonization for NE prevailing winds reservoir at $82 \mathrm{~m}$ a.s. 1. 
Acknowledgments - Financial support was partially provided by EBY (Entidad Binacional Yaciretá) and CONICET (Consejo Nacional de Investigaciones Científicas y Técnicas), Argentina.

\section{REFERENCES}

ALLANSON, B. R., HART, R. C., O'KEEFFE, J. H. \& ROBARTS, R. D., 1990, Inland waters of Southern Africa: an Ecological Perspective, Kluwer Acad. Publ., The Netherlands, pp. 221-284.

BARROW, C. J., 1987, The environmental impacts of the Tucuruí reservoir on the middle and lower Tocantins River Basin Brazil. Regulated River, 1: 49-60.

BOND, W. S. \& ROBERTS, M. G., 1978, The colonization of Cabora-Bassa Mozambique, a new man-made lake by floating aquatic macrophytes. Hydrobiologia, 60: 243259.

BONETTO, A. A., 1986, The Paraná River System. pp. 541551. In: K. F. Walker \& B. R. Davies (eds.), The Ecology of River Systems. Dr. W. Junk Publishers, The Netherlands, Dordrecht, 541-551.

BONETTO, A. A. \& LANCELLE, H. G., 1981, Calidad de las aguas del Río Paraná medio. Principales características físicas y químicas. Comunic. Científicas CECOAL, 11: 1-22.

CANFIELD, D. E., LANGELAND, K. A., LINDA, S. B. \& HALLER, W. T., 1985, Relations between water transparence and maximum depth of macrophytes colonization in lakes. Jour. Aquat. Plant. Management, 23: 2528.

CARIGNAN, R. \& NEIFF, J. J., 1992, Nutrient dynamics in the floodplain ponds of the Paraná River (Argentina) dominated by the water hyacinth Eichhornia crassipes. Biogeochemistry, 17: 85-121.

CUADRADO, G. \& NEIFF, J. J., 1993, Palynology of embalsados in distrophic lakes in Northeastern Argentina. Rev. Brasil. Biol., 53(3): 443-451.

JUNK, W. J. \& de MELLO, J. A. N., 1987, Impactos ecológicos das represas hidrelétricas na bacia amazônica brasileira, pp. 367-385. In: G. Kohlhepp \& A. Schrader (eds.), Homem e Natureza na Amazônica. Tübinger Geographische Studien 95 (Tübinger Beiträge zur Geographischen Lateinamerika-Forschung 3). Geographisches Institut, Universität Tübingen, Tübingen, Germany, 507p.
NEIFF, J. J., 1986a, Aquatic plants of the Paraná System, pp. 557-571. In: K. F. Walker \& B. R. Davies (eds.), The Ecology of River Systems. Dr. W. Junk Publishers, The Netherlands, Dordrecht.

NEIFF, J. J., 1986b, Las grandes unidades de vegetación y ambiente insular del Tío Paraná en el tramo CandelariaItá Ibaté. Rev. Asoc. Cienc. Nat. Litoral, 17(1): 7-30.

NEIFF, J. J., 1996, Large rivers of South America. Toward the new approach. Verh. Internat. Verein. Limnol., 26: 167-180

NEIFF, J. J. \& POI de NEIFF, A. S. G., 1979, Estudios sucesionales en los camalotales chaqueños y su fauna asociada. I. Etapa seral Pistia stratiotes-Eichhornia crassipes. Physis, B-37(95): 29-39.

PAGGI, A. C., CESAR, I. I. \& RODRIGUES CAPITULO, A., 1998, Benthic studies in the zone of islands of Yacyretá prior to impoundment of the Upper Paraná River (Argentina). Verh. Internat. Verein. Limnol., 26: 10891094. Stuttgart.

THORNTON, J. A., 1987, Aspects of eutrophication management in tropical-subtropical regions. J. Limnol. Soc. Sth. Afr., 13(1): 25-43.

TUNDISI, J. G., MATSUMURA-TUNDISI, T. \& CALIJURI, M. C., 1993, Limnology and Management of Reservoirs in Brazil, pp. 25-55. In: M. Straškraba, J. G. Tundisi \& A. Duncan (eds.), Comparative Reservoir Limnology and Water Quality Management. Kluwer Academic Publ., The Netherlands.

VAN DER HEIDE, J., 1982, Lake Brokopondo: Filling phase limnology of a man-made lake in the humid tropics. $\mathrm{Ph}$. D. Diss., U. Amsterreservoir.

VAN DER LINGEN, M. I., 1973, Lake Kariba: Early history and South shore, pp. 132-142. In: Ackermann et al. (eds.), Man-made lakes: their problems and environmental effects. American Geophysical Union, Washington.

VARELA, M. E., BECHARA, J. A. \& ANDREANI, N. L., 1983, Introducción al estudio del bentos del Alto Paraná. Argentina, Ecosur, 30(19/20): 103-126. 